\title{
The Study on Industry Relevance-A Case of Electronic Enterprise
}

\author{
Jian-Qiang GUO',a, Yan-Yan LIANG ${ }^{2, b}$, Jin-Ling FAN ${ }^{3, c}$ \\ ${ }^{1}$ School of Business, ShandongUniversity (Weihai), Weihai, 264200, China \\ ${ }^{2}$ School of Business, ShandongUniversity (Weihai), Weihai, 264200, China \\ ${ }^{3}$ School of Business, ShandongUniversity (Weihai), Weihai, 264200, China \\ ajgsxcz@eyou.com, bliangyanyan89@163.com, c13869099153@163.com
}

Keywords: Industry relevance, Electronic communication, Case.

\begin{abstract}
This paper study the future of industry drive and the contribution to the national economy of electronic communications on the background of region, from the perspective of the production and management and industry relationship of specific industries. The research shows that, the development of electronic communications industry and the leading role on the economy should pay more attention to the connection of industry development regionally and the given industry, and the contribution to the national economy.
\end{abstract}

\section{Introduction}

The electronic communication enterprise of Tianjin in the forefront of the introduction of foreign capital enterprise has its uniqueness. We firstly build up the industrial chain model of one representative enterprise in electronic communication industry using the theory of industry relevance, then investigate the related data to research the production and management of the foreign enterprise in this area. This article aims to find many valuable conclusions or some questions, which will facilitate the development of electronic communication industry and improve the efficiency of foreign investment and allocate social capital rationally.

\section{Situation of industrial relevance}

Industry interrelated theory analysis the wide and complex proportional relations of technology and economics between industries in the process of economic development from the angle of the "quantity" statically, also known as the input-output theory. According to the interdependence on the input and output, we can build up the Industry interrelated theory and industrial chain theory of electronic communication industry and summarize the unique characteristics of the industrial chain. In this paper, we investigate a representative electronic components machining enterprise of Sino-foreign joint ventures. The circuit boards are widely used in all areas, including emerging industries and high-tech industries, and traditional industries. The downstream enterprises are for the production of terminal product, which involves E-communication, aerospace, automobile manufacturing, automatic control, residential surveillance, instrument, etc. The upstream enterprises are for the supply of raw materials. The main ingredients are copper foil, printing ink and CCL (copper-clad laminate) made by copper, fiberglass and resin. The auxiliary materials include chemicals, general chemical products (sulfuric acid, hydrochloric acid, etc.), packaged products and finished goods. Among these upstream enterprises, some are foreign companies mastering modern technology; some are domestic individual proprietorship or joint ventures with advanced technologies. The difference between domestic products and imports is that the former can be manufactured by the Chinese or foreigners, but foreign goods may not be made in China because of the demand of high technology and value-added.

\section{The characteristic of industrial chain}

Industry chain is a new form of spatial organization among related enterprises of given industry 
cluster based on the theory of value chain. The enterprises in the industry chain have the long-term strategic partnerships. The industry chain in this article means that one electronic communication enterprise with competitiveness or potential competence form a strategic alliance in industry cluster. Now, we can use the following industry chain diagram to show the industry chain of the investigated company.

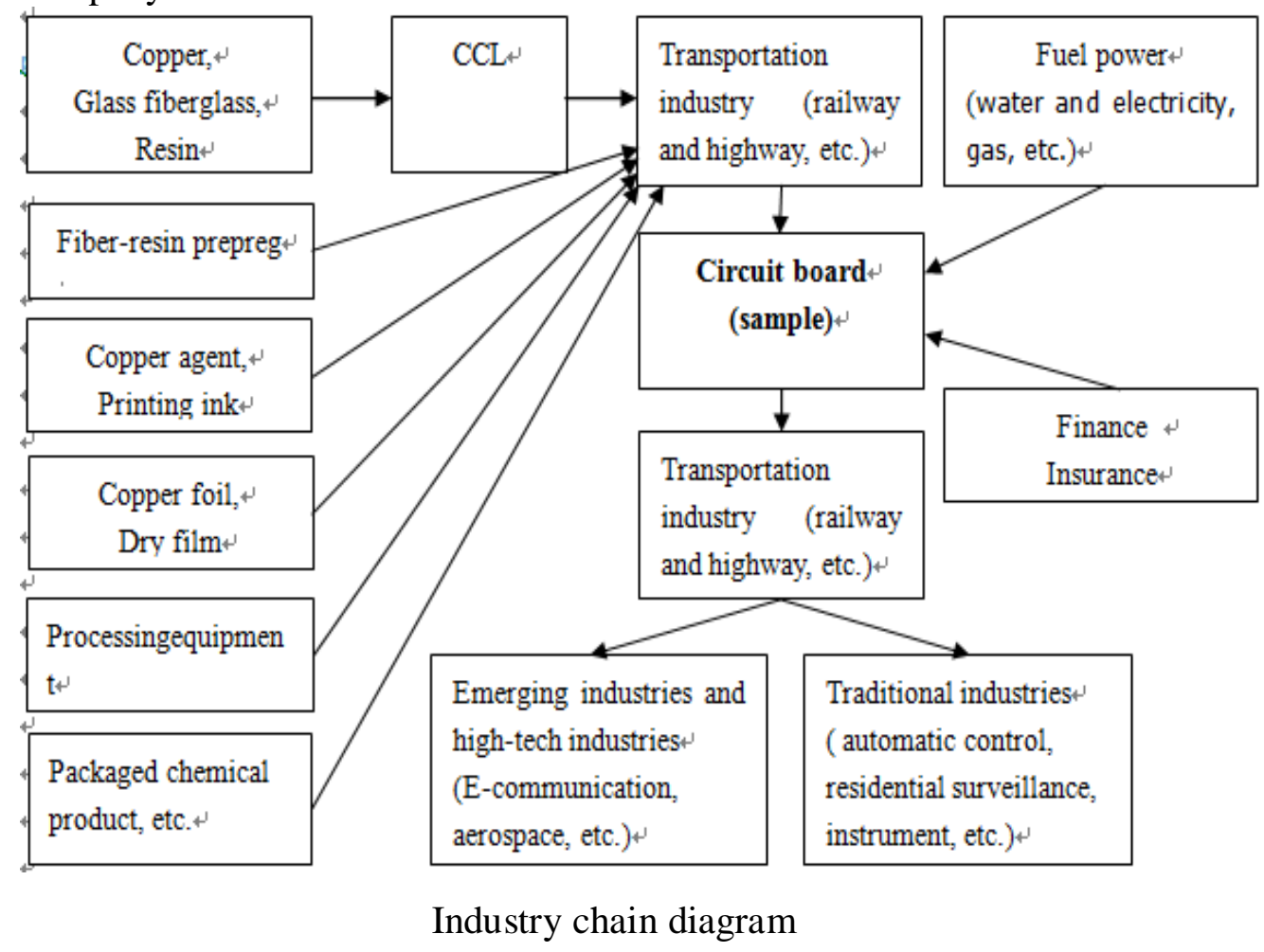

From the above schematic diagram, we can find that the investigated enterprise producing circuit boards lies in a basic position with its upstream enterprises which is the foundation of the basic industries. The upstream enterprises are mainly material industries, or some chemical ingredients industries. The development of these basic industries is the foundation of the production of electronic components such as circuit board. Then the circuit board is the foundation of the development of terminal products. On the other hand, the terminal products provide market and power for the development of upstream enterprises. Besides, the technological innovation of this industry comes up to satisfy the requirements of terminal industries by upstream enterprises or both. The processing of circuit board needs high technology and technique, in which the precision of the production equipment is very high. At present, the circuit boards are produced by joint ventures and other enterprises can't guarantee the quality.

From the industrial connection diagram and the table of production supply and marketing link, we obtain the industrial chains characters of this enterprise in Communication-Electronics industry.

First, the production of circuit board in this enterprise can reach domestication basically. Although the technology of some key material hasn't been mastered, it doesn't affect product basically, and the amount and proportion introduced has been reduced year after year. Some technologies can learned gradually in the process of producing and developing, but some technologies cannot be obtained in a long time.

Second, the driving effect of joint enterprises and individual proprietorship enterprises is very big. From the condition of the enterprise's source of using materials, there is about materials of 31.3 million Yuan (which occupies about $58 \%$ of the total domestic materials) which are provided by the joint enterprises or individual proprietorship enterprises.

Third, the matching production capacity in Tianjin areas is insufficient, lots of the matching production capacity comes from other areas, and it doesn't form the pattern of cluster production. The capacity of material provided in Shanghai and Guangdong is far greater than that of Tianjin, for example, the Copper Clad Laminate produced in Guangdong is the main material of 
circuitboardproduced in Tianjin, which occupies more than $30 \%$ of the total materials or the total value of materials. And according to the regional distribution data of circuitboard production in nationwide, the main production capacity concentrates in Guangdong dialects. Because the main material of circuitboard produced by this enterprise is from Guangdong, thus, from the synergistic effect of cluster production, it is a bigger waste undoubtedly, which should be highly regarded by the government. And it may be one aspect that restricts the development of this industry in this area.

Forth, the driving effect of enterprise is influenced by the character of its electronic components processed enterprises, and the biggest driving effect is from big enterprises and the main enterprises, which produce end-use products generally. And in general, it is the other industries that drive circuitboard to develop, rather than circuitboard drives the other industries. The driving effect of circuitboard production mainly reflect in driving the basic industries, for example the material industries which stay upstream.

Chart 1 The industrial relevance of supply chain

\begin{tabular}{|c|c|c|c|c|c|c|c|}
\hline \multicolumn{2}{|c|}{$\begin{array}{l}\text { Items } \\
\text { Regional } \\
\text { distribution }\end{array}$} & $\begin{array}{l}\text { Product } \\
\text { category }\end{array}$ & $\begin{array}{l}\text { Demand } \\
\text { for tech } \\
\text {-nology }\end{array}$ & Property & $\begin{array}{l}\text { Futures } \\
\text { of } \\
\text { products }\end{array}$ & $\begin{array}{l}\text { Value } \\
\text { added }\end{array}$ & $\begin{array}{l}\text { The degree } \\
\text { of } \\
\text { localization }\end{array}$ \\
\hline \multirow{4}{*}{ China } & Tianjin & $\begin{array}{l}\text { Medical } \\
\text { products } \\
\text { Packing } \\
\text { box, etc. }\end{array}$ & $\begin{array}{l}\text { General } \\
\text { medical } \\
\text { products, } \\
\text { auxiliary } \\
\text { material }\end{array}$ & $\begin{array}{l}\text { state } \\
\text {-owned } \\
\text { enterprise }\end{array}$ & $\begin{array}{l}\text { Up to } \\
\text { standard }\end{array}$ & Lower & $\begin{array}{l}\text { Domestic } \\
\text { overall }\end{array}$ \\
\hline & \multirow{3}{*}{$\begin{array}{l}\text { Guang } \\
\text {-dong } \\
\text { and } \\
\text { Shang } \\
\text {-hai }\end{array}$} & CCL & $\begin{array}{l}\text { high } \\
\text { machinin } \\
\text { g } \\
\text { process }\end{array}$ & $\begin{array}{l}\text { Foreign } \\
\text { individual } \\
\text { or joint } \\
\text { ventures }\end{array}$ & High & High & $\begin{array}{l}\text { Domestic } \\
\text { basically }\end{array}$ \\
\hline & & Dry film & $\begin{array}{l}\text { High } \\
\text { content }\end{array}$ & $\begin{array}{l}\text { Foreign } \\
\text { individual } \\
\text { ventures }\end{array}$ & High & High & $\begin{array}{l}\text { Packing in } \\
\text { China }\end{array}$ \\
\hline & & $\begin{array}{l}\text { Fiber } \\
\text {-resin } \\
\text { prepreg }\end{array}$ & $\begin{array}{l}\text { High } \\
\text { content }\end{array}$ & $\begin{array}{l}\text { Foreign } \\
\text { individual } \\
\text { ventures } \\
\text { (Japan, } \\
\text { German, } \\
\text { England) }\end{array}$ & High & High & $\begin{array}{l}\text { Import } \\
\text { partly }\end{array}$ \\
\hline \multirow{3}{*}{\multicolumn{2}{|c|}{ foreign }} & $\begin{array}{l}\text { Copper } \\
\text { agent }\end{array}$ & $\begin{array}{l}\text { Copper } \\
\text { agent, }\end{array}$ & $\begin{array}{l}\text { Foreign } \\
\text { enterprises }\end{array}$ & High & High & $\begin{array}{l}\text { Import } \\
\text { overall }\end{array}$ \\
\hline & & $\begin{array}{l}\text { Copper } \\
\text { foil }\end{array}$ & $\begin{array}{l}\text { Copper } \\
\text { agent }\end{array}$ & $\begin{array}{l}\text { Foreign } \\
\text { enterprises } \\
\text { (Japan) }\end{array}$ & High & High & $\begin{array}{l}\text { Import } \\
\text { overall }\end{array}$ \\
\hline & & $\begin{array}{l}\text { Printing } \\
\text { ink }\end{array}$ & $\begin{array}{l}\text { Copper } \\
\text { agent }\end{array}$ & $\begin{array}{l}\text { Foreign } \\
\text { enterprises }\end{array}$ & High & High & $\begin{array}{l}\text { Import } \\
\text { partly }\end{array}$ \\
\hline
\end{tabular}

\section{Conclusions and suggestions}

The statistical data of Ministry of commerce has apparently showed that the foreign-invested enterprises have become an important part of China's national economy. No matter from the total 
industrial added, or from the value of industrial output which comes from the foreign-invested enterprises accounting for the total value of industrial output in China, the leading role of the foreign-invested enterprises(or Sino-Foreign joint venture ) to national economic development and employment is very apparently. But we must pay more attention to some features.

Firstly, nationalization is still a problem which is worth paying more attention. On the whole, the foreign-invested enterprises themselves are the representative of advanced technology or managerial experience, and the emergency of them is good for the development of our economy. But the driving effect of foreign-invested enterprises forms by technology transfer and demonstration effect, and the dimension of driving effect depend on the dimension of industrial linkage. In general, the bigger the related degree is, the more apparent the driving effect is. However, the entrance of some multinational corporations is reserved apparently, and some key technologies won't enter into China readily. However, the key technologies are the base of high added-value. They control the key technologies and stay conservative in transferring the software of production and organization, which is very bad for related industries in our country, and it will greatly weakened the spillover effect of foreign-invested technologies. In the future, at the same time of self-developing, we should pay more attention to the transmission of foreign-invested technologies, and we should try our best to import their key technologies and managerial experience.

Secondly, we should notice the production of industrial cluster, and production of localization is one important aspect of industrial cluster. As a new form of industrial space organization, industrial cluster form the competitive advantages with longer industrial chains, concentration in talent, competitive form, cooperation and so on. In importing foreign capital of the investigated areas in Tianjin, which have unique conditions, but the E-communication's localized production hasn't formed, at least it hasn't reached the degree of functioning. So from the perspective of industrial development's coordination, we should notice the correlation of imported enterprises or technologies and domestic enterprises, and we should notice whether we can extend the existing industrial chains or develop the level of existing industrial technologies, and we should also notice coordinated development in the supplement of material, the supplement of talent, Infrastructure construction, the supplement of capital, and the selling environments, thus it can enhance the industrial development potential and industrial competitiveness of these areas.

Thirdly, the driving effect of the main enterprises is very apparent. Because these large enterprises not only form larger national output, provide considerable opportunities of employment and financial income, but also create market demand, and it pulls and boosts the output value of some enterprises, which has global effect to related industrial development. Thus, basing on the industry interrelated theory, we should notice the import of large enterprises to enhance the competitiveness of the whole industry, meanwhile, and we should notice the coordinated development of every department in the industry.

Although these characters above aim at the areas in Tianjin, they are fit the national condition on a large scale, which has certain enlightenment function to the behaviors showing only notice the quantity of foreign capital introduction, but not notice the inner structure and efficiency of foreign capital introduction. The actual analysis shows that the key to foreign capital introduction are the introduction of production capacity, the introduction of industrial efficiency and the introduction of the key enterprises. And we should notice the coordination of foreign capital introduction and the regional development of industries.

\section{References}

[1]Zhang J, Liu Z, Zheng J. Industrial Chain Positioning, Divide, Agglomeration and Innovation: An Empirical Study Based on Questionnaire of Manufacturing Firms in Jiangsu Province. J. China Industrial Economy, 2007, 7: 007.

[2] Zhipei Feng, Zhiying Liu, The historical evolution and review of the industry relevance. J. Journal of Wenzhou University. 2005, (1): 51. 
[3] Guojun Jiang, Mingxin Jinang, The study on the theory of industrial chain and its stabilizing mechanism. J. Journal of Chongqing University (social science edition). 2004(1): 37.

[4] Yue Li, Ping Li, Industry economics. Northeast University of Finance and Economics press.2004: 32. 